\title{
A República no Rio Grande do Sul: política, etnia e religião
}

\author{
The Brazilian Republic in Rio Grande do Sul: Politics, ethnicity and religion
}

René E. Gertz ${ }^{1}$

gertz@pucrs.br

\begin{abstract}
Resumo. A proclamação da República brasileira, em 1889, foi percebida de diferentes formas pelos vários grupos étnicos e religiosos que compunham a nação, naquele momento. Aqui, são analisadas as reações dos católicos de origem alemã no estado do Rio Grande do Sul, através da fundação do Partido do Centro ou Partido Católico, logo após a instituição do novo regime, bem como as tentativas feitas, sobretudo por luteranos, para fundar um Partido Colonial.
\end{abstract}

Palavras-chave: castilhismo, catolicismo, imigração alemã.

Abstract. The proclamation of the Brazilian Republic in 1889 was perceived in different ways by the various ethnic and religious groups that formed the Nation at that time. Here we analyze the reactions of Catholics of German descent in Rio Grande do Sul, immediately after the institution of the new regime, through the establishment of the Party of the Center ("Partido do Centro") or the Catholic Party ("Partido Católico"), as well as the efforts made mainly by Lutherans, who founded a Colonial Party ("Partido Colonial").

Key words: Castilhism, Catholicism, German immigration.

Devo começar alertando que minha fala será ainda mais restrita do que se pode imaginar a partir do título. Naquilo que tange à política, sim, serão feitas algumas poucas referências à política republicana gaúcha num sentido um pouco mais geral, mas naquilo que se refere a etnia, falarei, de fato, apenas da assim chamada "colônia alemã" no estado - e, concretamente, isso se dará através de referências a manifestações e ações de indivíduos ou de grupos de elite. Como a população e as elites dessas regiões pertenciam a duas confissões religiosas - a católica e a luterana -, sob este aspecto, o leque se abrirá um pouco mais, pois serão feitas referências a ambas.

Cronologicamente, minhas apreciações se estenderão do final do império até os primeiros anos da República, para que se tenha não apenas uma visão sincrônica do contexto mais imediato em torno do dia 15 de novembro de 1889 , 
mas também da inserção num espaço temporal um pouco mais amplo, a fim de superar algumas visões estanques sobre esse tema, que eu chamaria de visões "generalistas", quando alguns autores - incluindo acadêmicos - falam da posição da "colônia alemã", da posição dos católicos ou da posição dos luteranos, no momento da proclamação da República. A realidade histórica costuma ser um pouco mais complexa, e o máximo que se consegue estabelecer, com alguma segurança, são, via de regra, "tendências", mas raramente se podem fazer generalizações absolutas.

Não se falará aqui das populações originárias das imigrações italiana e polonesa, que, sem dúvida, adquiriram importância econômica, social e política no decorrer do período republicano, simplesmente porque, em 1889, elas se encontravam havia menos de 15 anos em território gaúcho, e, consequentemente, todos os adultos que as compunham eram estrangeiros e suas comunidades ainda estavam em processo de estruturação - enquanto a imigração alemã começara 65 anos antes, estando mais solidamente estabelecida, e já com percentual significativo de cidadãos brasileiros natos. Parte dessa população estava envolvida, há bastante tempo, na administração pública e, portanto, na política local. Assim - para exemplificar -, os primeiros integrantes de sobrenome alemão haviam ingressado na Câmara de Vereadores de São Leopoldo em 1849, em 1864 a maioria dos sobrenomes da Câmara local já era constituída de pessoas de sobrenome alemão, e o percentual de nomes dessa origem étnica aumentou ainda mais à medida que o tempo se aproximava de 1889 (Gertz, 2006,p. 59 ss.).E em Santa Cruz do Sul foi eleita, em 1880, a primeira Câmara de Vereadores composta exclusivamente por pessoas de sobrenome alemão no Rio Grande do Sul (Deutsche Zeitung, 1880b, 10 de julho).

Devido a esse processo mais antigo, a população de origem alemã registrava, em 1889, uma presença mais marcante na província do que os outros dois grupos citados, chegando a considerar-se que alemães e descendentes constituíam cerca de um oitavo de toda a população gaúcha, e que em vários municípios sua presença era tão significativa que eles podiam ser classificados como típicos de colonização alemã. Entre esses municípios destacavam-se: Taquara, São Leopoldo, São Sebastião do Caí, Montenegro, Estrela, Lajeado, Venâncio Aires, Santa Cruz do Sul - e, numa posição geográfica diferente, cabe citar ainda São Lourenço do Sul (Gertz, 1994). ${ }^{2}$

Iniciemos por algumas dessas lógicas que chamei de "generalizantes" sobre a posição de alemães e descendentes frente ao republicanismo. Há toda uma tradição na cultura historiográfica brasileira e gaúcha de que a integração político-cultural à realidade brasileira dessa população sempre teria sido extremamente restrita e que, por consequência, teriam ficado preservadas, em alto grau, suas características culturais, como a língua, fortalecendo a identidade intragrupo e conservando estreitos laços - reais ou apenas afetivos - com a pátria de origem, a Alemanha. $\mathrm{Se}$, de fato, fosse assim, não seria errado imaginar que essa população se mantivesse essencialmente monarquista, já que essa era a forma de governo que vigorara no antigo Sacro Império Romano-Germânico, depois nos muitos pequenos reinos e principados alemães e, finalmente, a partir de 1870, se vivia sob uma Monarquia que unificara essas diferentes entidades estatais. E essa simpatia pelo sistema monárquico determinada pela tradição do país de origem poderia ter experimentado um reforço no fato de que o imperador brasileiro D. Pedro II tinha aquilo que se costumava chamar de "sangue alemão", já que sua mãe, a princesa Leopoldina, pertencia à dinastia dos Habsburgos e era "bisneta da grande imperatriz alemã Maria Teresa e filha de Francisco II, último imperador do 'Sacro Império Romano-Germânico' e primeiro imperador da Áustria”como se pode ler no livro clássico sobre a "contribuição teuta à formação da nação brasileira", de Oberacker Junior (1978, p. 170).

Mas poderíamos, também, inverter essa lógica. Partindo dos dados objetivos de que vieram mais imigrantes alemães luteranos do que católicos para o Brasil, e de que o sistema constitucional brasileiro do período imperial limitava o exercício pleno da cidadania a naturalizados e a não-católicos, poderia imaginar-se que o Partido Republicano, com suas propostas de laicização do Estado brasileiro, tivesse obtido ampla repercussão entre a população da assim chamada "colônia alemã". Nessa mesma perspectiva, a cultura historiográfica sobre a imigração e a colonização alemã está repleta de referências sobre supostas ou efetivas tendências autonomistas e de auto-organização da população "colonial" - isso se ouve ou se lê nas referências à organização de associações recreativas, escolares, religiosas e também econômicas, quando, por exemplo, se festeja essa população como fundadora do sistema cooperativista no estado e no próprio país. Significa que seria lógico esperar que, entre essa população, houvesse amplas simpatias pela insistência do programa republicano na descentralização política e administrativa, na defesa da autonomia de estados e municípios.

Uma terceira lógica aponta para a importância econômica que, no final do século XIX, haviam adquirido as "colônias alemãs" em grandes cidades, como Porto Alegre, mas também as do interior. Poderia dizer-se que

${ }^{2}$ Alguns desses municípios só foram criados após a proclamação da República (como Lajeado e Venâncio Aires - 1891), mas isso não invalida a afirmação de que constituíam comunidades com grau de evolução socioeconômica e política que os equiparava a municípios constituídos havia mais tempo. 
se tratava de uma população que participava ativamente do processo de implantação de um capitalismo moderno no estado. Os republicanos históricos em geral, mas, no nosso caso, sobretudo os gaúchos, muitas vezes, foram vistos e apresentados como propugnadores de um projeto de modernização capitalista. Aqui, uma explicação mais materialista também poderia deduzir uma correspondente afinidade entre o projeto dos republicanos gaúchos e a população de origem alemã. ${ }^{3}$

Há ainda outras lógicas possíveis, mas as três citadas são suficientes para exemplificar e sugerir que essas lógicas não bastam, que é necessário investigar o processo histórico real e tentar compreendê-lo - ou não. É muito frequente que determinadas lógicas ou supostas obviedades históricas se mostrem totalmente infundadas quando submetidas a uma criteriosa pesquisa. E, nesse sentido, um primeiro dado concreto é que, nos aproximadamente últimos dez anos da Monarquia, o senador gaúcho Gaspar Silveira Martins, do Partido Liberal, foi uma figura bastante conhecida, e até popular, em várias regiões de colonização alemã, apresentando-se como defensor dos interesses de suas populações. Karl von Koseritz - considerado a maior liderança da "colônia alemã" na época - escreveu no seu jornal Deutsche Zeitung (1880a), de 3 de janeiro de 1880, que ele, Silveira Martins,

reconhece que o período áureo do elemento românico passou, que a direção do mundo civilizado está hoje nas mãos dos germanos. Ele tem uma mente aberta para os sucessos no campo do progresso e da ciência. Ele prova que os germanos são os verdadeiros portadores da cultura, e é por isso que ele assumiu a luta, pois o que quer é ver sua pátria grande, rica, próspera, sem perguntar por diferenças raciais.

A ação do senador mais frequentemente referida pela memória histórica é a da luta pelos direitos civis de naturalizados e, sobretudo, de não-católicos, que teria desembocado na Lei Saraiva, de 1881, que concedeu esses direitos. Quando Koseritz soube que a aprovação dessa lei estava garantida, escreveu que o próprio país talvez não soubesse

que enorme passo deu, pois caiu o último empecilho que até agora restringia uma imigração moralizadora e eficiente para atrair trabalhadores. Essa decisão trará ao Brasil maiores ganhos do que 50 anos de discussóes
Saraiva e a Pelotas, mas, sobretudo, honra ao conselheiro Silveira Martins, que foi quem tomou a iniciativa nesse importante assunto (Deutsche Zeitung, 1880c, 3 de novembro).

A partir daí, vamos ter o ingresso de cinco deputados de sobrenome alemão na Assembleia Provincial gaúcha, nos últimos oito anos da Monarquia. Foram eles: Frederico Guilherme Bartholomay, Frederico Haensel, Karl von Kahlden, Karl von Koseritz, Wilhelm ter Brüggen (Motter, 1998). O fato de apenas um deles (Brüggen) ter pertencido ao Partido Conservador, e os outros quatro ao Partido Liberal, sugere que a ação do senador Gaspar Silveira Martins pode ter rendido dividendos. Além disso, o fato de essa bancada de cinco deputados ter sido muito pouco católica sugere que a questão da cidadania para não-católicos foi um tema importante.

Em contraposição, um levantamento dos nomes mais diretamente ligados à construção do Partido Republicano Riograndense mostra que entre eles havia poucos alemães, e entre esses poucos havia alguns que não representavam regiões típicas de colonização ou eram defensores declarados de seus interesses (Pinto, 1979). Além disso, uma avaliação sobre o posicionamento de alguns líderes do jovem partido republicano no Rio Grande do Sul mostra que muitos deles manifestavam profundas reservas contra a população de origem alemã. No jornal $A$ Federação, podiam ser lidos - no decorrer da década de 1880 - conteúdos daquilo que se costumava chamar de manifestações "nativistas" ou de alerta contra o "perigo alemão", isto é, declarações no sentido de que a população de origem alemã da província faria parte - ou poderia vir a fazer - de um projeto de expansão imperialista da Alemanha.

Manifestações desse tipo também apareciam na imprensa conservadora. Assim, o jornal O Conservador, por exemplo, escreveu que o Brasil necessitaria de uma imigração que trouxesse força de trabalho e capital; e, para atrair a ambos, bastaria o clima e a fertilidade do solo brasileiros; imigrantes que viriam por outras razões que seu bem-estar pessoal não seriam desejados, principalmente aqueles que quisessem tornar-se ministros e deputados, pois a honra da nação seria por demais altiva para servir de tapete para os imigrantes limparem sua escandalosa sujeira; a eleição de pessoas de sobrenome alemão para a Assembleia Provincial chegou a ser classificada como grande vergonha nacional (Gertz, 2005, p. 139 ss.).

3 Detalhes, inclusive historiográficos, sobre essa interpretação podem ser vistos no importante texto de Helga Piccolo sobre o tema. Não significa que a autora endossasse essa visão. Pelo contrário, ela mostra outras variáveis e a complexidade do tema (Piccolo, 1982). Referências sobre como é visto, pela cultura historiográfica, o transcurso da Revolução Federalista nas regiões de colonização, nos primeiros anos da República, com base em pressupostos semelhantes, podem ser buscadas em Gertz (1993a). 
Mais do que deduzir dessas manifestações alguma conclusão definitiva sobre o posicionamento de conservadores e republicanos a respeito da população de origem alemã, elas sugerem que, na opinião pública gaúcha, estava muito difundida a impressão de que, naquele momento, essa população vivia uma bastante generalizada aproximação política ao Partido Liberal. $\mathrm{E}$ foi dentro desse contexto que ocorreu a proclamação da República.

A historiografia corrente costuma deduzir aqui mais uma lógica: como os conservadores, no momento da proclamação, estavam na oposição, tenderam a aderir ao republicanismo após a extinção da Monarquia, de forma que a polarização política do momento se dava entre republicanos, somados aos conservadores, contra os liberais. Deduzem-se, dessa lógica, inclusive efeitos de longo prazo sobre a inserção política das regiões de colonização alemã. Essa lógica aponta no sentido de enxergar-se na aliança em curso com Gaspar Silveira Martins e seu Partido Liberal o rompimento das históricas barreiras políticas e de integração mais geral dos imigrantes e de seus descendentes, com avanços significativos durante a década de 1880 - quando a presença dos cinco citados deputados de sobrenome alemão na Assembleia Provincial evidenciaria esses avanços. Mas essa situação teria, justamente, feito com que a proclamação da República encontrasse a população de origem alemã, politicamente, no lado errado e, por consequência, teria posto fim ao processo de integração finalmente iniciado após a Lei Saraiva, representando, portanto, um retrocesso, com efeitos que teriam persistido por décadas.

Nesse sentido, no famoso livro-padrão de Jean Roche sobre A colonização alemã e o Rio Grande do Sul, o autor resume seu pensamento a respeito das consequências da ascensão dos republicanos ao poder nos seguintes termos:

Com efeito, não se preocupavam com deixar aos colonos [...] a liberdade política pela qual a constituição castilhista do estado dobrava a finados. A democracia rural que se constituíra nas colônias [durante o Império] [...] deixou de participar da vida politica do Rio Grande, nele se incrustou, tornando-se de novo estranba a seu organismo. [...] os riograndenses de origem alemã, agora cidadãos, eram, uma segunda vez, postos à margem do Estado (Roche, 1969, p. 711-712).
Essa interpretação tornou-se clássica na historiografia sul-rio-grandense. Assim - só para dar um exemplo posterior -, Hélgio Trindade, em seu estudo sobre partidos e eleições no Rio Grande do Sul de 1823 a 1990, escreveu a respeito do período de transição do império para a República que, sobretudo sob a liderança de Karl von Koseritz, estava se estabelecendo um "primeiro elo da articulação política da comunidade teuto-riograndense com seu meio. Esta ruptura causada pela ausência de uma estratégia integracionista dos setores imigrantes começa a ser superada apenas no fim da década de [18]80. A República, sob a liderança dos castillistas no RS, seria um rude golpe nesse ensaio de quebra do isolamento" (Trindade e Noll, 1991, p. 37-38). ${ }^{4}$

Ainda que não se possa comprovar a falsidade dessa interpretação e ainda que ela, certamente, apresente algum grau de veracidade, a realidade concreta é um pouco mais complexa. Se, de fato, entre as pessoas de sobrenome alemão presentes no rol dos republicanos históricos gaúchos, Germano Hasslocher e Augusto Ufflacker não se apresentassem muito "germânicos", temos também a presença de Luís Englert que, certamente, estava mais próximo da "colônia", pois era militante católico na Igreja São José, de Porto Alegre, que era cognominada de "dos alemães". Além disso, há um aspecto sobre o qual faltam pesquisas - refiro-me a eventuais contatos de republicanos com pessoas representativas da "colônia alemã”. Um dos campos em que esse contato pode ter-se dado é a maçonaria. Como se sabe, ela estava bastante difundida entre a população de origem alemã. Da mesma forma, sabe-se que muitos republicanos eram militantes da mesma - ainda que isso também acontecesse com monarquistas (basta citar Gaspar Silveira Martins). O comerciante Carlos Huber, por exemplo, representante destacado da "colônia alemã" de Porto Alegre, maçom, era apresentado como grande amigo de Julio de Castilhos (Kalender für die Deutschen in Brasilien, 1903, p. 169-171). Também atividades profissionais podem ter intermediado contatos. Um Centro Clínico estabelecido ao final do Império pelos médicos Jorge Fayet e Carlos Wallau ambos vistos como representantes típicos da "colônia alemã" de Porto Alegre - contava entre seus sócios com o republicano Protásio Alves, figura de destaque após a proclamação da República. Política, maçonaria e profissão poderiam estar presentes num mesmo tipo de relação dessas - na década de 1880, desenvolveu-se em Santa Maria um rumoroso caso envolvendo o coronel Martin Höhr, que foi defendido pelos advogados Graciano de

${ }^{4}$ Os itálicos foram acrescentados ao original, tanto na citação de Roche quanto na de Trindade e Noll. A afirmação está repetida na versão de 2004 do livro de Noll e Trindade (2004, p. 45). 
Azambuja,Julio de Castilhos e Oscar Rheingantz, caso no qual os três ingredientes se juntaram. ${ }^{5}$

Esses são apenas alguns poucos exemplos para indicar, mais uma vez, que é difícil fazer generalizações categóricas sobre a relação dos republicanos com a "colônia alemã". Cabe também não esquecer as grandes diferenças que, com certeza, existiam entre as elites e as "bases" dentro das próprias "colônias". Se olharmos para aquilo que disseram os principais jornais logo depois da proclamação da República, vamos ver que o jornal da mais destacada liderança "colonial" do momento, Koseritz, manifestou sua contrariedade à nova forma de governo. Já o jornal do conservador ter Brüggen escreveu que "como qualquer outra forma de Estado, também a republicana necessita de um partido sustentador, isto é, conservador, pelo simples fato de que, no decorrer do tempo, necessariamente surgirá alguma tendência radical" (Deutsche Zeitung, 1889, 19 de novembro). Essa frase sugere que ter Brüggen não descartava a colaboração do Partido Conservador na administração da nova República. Já o jornal Deutsche Post do pastor luterano Wilhelm Rotermund, de São Leopoldo, a mais destacada liderança dos luteranos gaúchos, recomendou "manter a calma e a liberdade", sugerindo também disposição para alguma forma de negociação (Fausel, 1936, p. 198).

As manifestações feitas em editoriais de jornais refletiam, naturalmente, os posicionamentos de uma elite. Infelizmente, temos poucos relatos sobre a atitude de setores mais amplos da população, como, por exemplo, uma carta de Agudo, publicada na Deutsche Zeitung (1890a) em 6 de maio, portanto, quase seis meses após o 15 de novembro: "Como fomos libertados do jugo que oprimiu a colônia Santo Ângelo [mais tarde Agudo] por cerca de 30 anos, nós atiradores da Picada Bohemia fizemos a festa de sagração de nossa bandeira [da sociedade] sem nosso jugo, isto é, sem nosso sócio-honorífico, senhor barão von K., que agora, graças a Deus está neutralizado." Ainda que aqui não haja qualquer referência à instauração da República, esta representou, de forma concreta, a saída do diretor da colônia, o deputado liberal barão von Kahlden, de maneira que a gente simples dali se alegrou porque recebeu um novo diretor na pessoa do republicano Paul Magnus Hellberg. Esse exemplo mostra que o posicionamento frente à República podia depender de muitas coisas - desde preceitos doutrinários até elementos da vida bem cotidiana.

Cerca de meio ano após a proclamação da República constituiu-se, em Porto Alegre, um Partido do Centro. A inspiração para esse partido foi um partido da
Alemanha com a mesma denominação, o qual congregava boa parte da população católica dentro do império alemão, no qual o luteranismo possuía um espaço de manobra bem mais amplo que o catolicismo. Portanto, assim como lá, também aqui tratava-se de um partido de oposição. $\mathrm{E}$ aqui a situação a que o novo partido se opunha era a recém-criada República. Os cinco pontos básicos do partido foram: (i) liberdade religiosa para o catolicismo, sem intromissão do Estado; (ii) isenção do serviço militar para clérigos e seminaristas; (iii) intangibilidade e garantia para as propriedades eclesiásticas; (iv) fim das escolas ateístas mantidas pelo Estado (as quais constituiriam uma malversação dos impostos e atentariam contra a liberdade religiosa), com liberdade de fundar escolas e definir seu ensino; (v) fim da obrigatoriedade do casamento civil (o qual constituiria um incentivo a uma vida desregrada).

Ainda que de inspiração alemã, o partido não foi produto exclusivo da "colônia alemã". Seus membros tentaram desencadear uma significativa campanha publicitária, que englobaria três jornais, um em português, outro em italiano e um terceiro em alemão. Para os leitores de língua portuguesa, foi criado, de imediato, ainda em maio de 1890 - mês de fundação do partido - o jornal Época. Em língua italiana, começou a circular em março de 1891 Il Corriere Cattolico. E naquilo que tange aos leitores de língua alemã, transferiu-se de São Leopoldo para Porto Alegre o Deutsches Volksblatt, jornal que era editado desde 1871 pelos jesuítas, na primeira cidade. Este último órgão de imprensa, certamente, deveria constituir um esteio importante para o novo partido, pois, para editá-lo, foi especialmente criada, em Porto Alegre, uma sociedade anônima dirigida pela destacada família católica Wallau - empresa que mais tarde passaria para a família Metzler, e durante décadas constituiria o centro editorial do catolicismo nas regiões de colonização alemã do Rio Grande do Sul.

As primeiras eleições do período republicano se realizariam em setembro de 1890 . A participação do Partido do Centro foi mais ou menos desastrada. Em primeiro lugar, os republicanos colocaram todos os empecilhos possíveis para impedir que ele obtivesse votos. De Bom Princípio se noticiou, por exemplo, que os eleitores católicos vinham com listas eleitorais nas quais constavam nomes de republicanos confiáveis para o catolicismo, ao lado dos especificamente "centristas", mas que agentes republicanos tomavam-lhes essas listas, riscavam os nomes do partido católico e os substituíam por outros republicanos, tornando-a integralmente governista. Em São José do Hortêncio, foram listados, nominalmente, 137

${ }^{5}$ Sobre o caso Martin Höhr, pode-se consultar Pistoia (2009). 
eleitores que afirmavam ter dado seu voto a candidatos católicos, mas no escrutínio oficial apareceram apenas 75 votos “centristas". De Santa Cruz do Sul, noticiou-se, no mesmo sentido, o depósito de 537 votos católicos, dos quais apenas 248 teriam aparecido na contagem oficial.

Mas, aparentemente, não foi somente a contraação governista a responsável por uma votação bastante baixa nos candidatos do Partido do Centro. Em termos numéricos, o candidato republicano menos votado entre aqueles que foram eleitos obteve 30.635 votos. $\mathrm{O}$ mais votado entre os "centristas" foi Carlos Wallau, com apenas 2.271 votos. Com exceção de Encruzilhada do Sul, os candidatos católicos haviam recebido votos em Porto Alegre, Gravataí e em diversos municípios de colonização alemã. Mesmo assim, também nestas últimas, houve queixas de que os paroquianos católicos pouco se haviam empenhado a favor da causa. Nominalmente, os jornais católicos citavam casos de pouco empenho na região de Estrela. Alguns padres se enfureceram com esse pouco empenho dos paroquianos. Em Santa Clara, próximo a Lajeado, o padre Maierhofer afirmou, na missa domingueira, que "no juízo final, Deus não perguntará apenas pelas boas obras e pela vida correta de cada um, mas ele também perguntará se vocês votaram no Partido Católico ou na República. Só podem salvar a alma aqueles que votaram nos candidatos do Partido Católico.” Algum tempo depois, na mesma região, o padre Haltmeier pregou furiosamente contra os republicanos, instigando seus paroquianos a combatê-los, pregação que resultou num confronto físico. ${ }^{6}$

Tudo indica, porém, que também as lideranças urbanas do partido católico não estavam muito convictas da capacidade de vida autônoma, enxergando-o, muito antes, como um grupo de pressão para viabilizar uma influenciação sobre o partido governista. Ainda antes das eleições de setembro de 1890, a Deutsche Zeitung, de Porto Alegre, publicou, em 22 de agosto de 1890, uma nota assinada com a letra "T", em que se afirmava o seguinte:

Nos princípios muito claros do Partido Católico, está o fator básico para que o Partido Católico vote a favor do governo, na firme conviç̧ão de que o governo não incomodará e muito menos proibirá nossos curas em seu trabalho, os quais até agora só trouxeram o bem e o útil. Sabemos muito bem que a felicidade e a salvação de todo o Brasil estão no fortalecimento de um vigoroso partido governamental, e estamos muito longe de querer representar um entrave ao desenvolvimento abençoado de um país que anseia pelo progresso. Deixem-se em paz os nossos curas e protejam-se os educadores de nossa juventude, e não se encontrarão republicanos menos exigentes e mais fiéis do que nós do Partido Católico (Deutsche Zeitung, 1890b, 22 de agosto, p. 2).

É que, desde o início, membros do partido faziam um jogo duplo. Assim, quando um grupo de republicanos publicou, no seu jornal partidário A Federação, um protesto pela não inclusão de Barros Cassal na nominata de candidatos, encontramos entre os 42 signatários desse documento o nome do citado Carlos Wallau, do Partido do Centro. E o mesmo movimento enxadrístico foi feito pelo Partido Republicano Riograndense, quando sugeriu que os eleitores de origem alemã que se sentissem prejudicados pela inexistência de qualquer sobrenome alemão na nominata republicana poderiam incluir na sua lista de votados os nomes do mesmo Wallau e de Luís Englert. Nesse contexto, os republicanos, inclusive difundiram a informação de que este último fora cogitado para integrar a lista republicana, mas que no momento de seu lançamento ainda não havia sido editado o decreto permitindo a candidatura de cidadãos naturalizados depois de 15 de novembro de 1889.

Essa aproximação recíproca de importantes setores católicos com republicanos teve como efeito o fato de que, nas eleições para a constituinte estadual, em 5 de maio de 1891, o Partido do Centro sugeriu apenas três candidatos e negociou sua inclusão na lista do Partido Republicano. Os três foram eleitos. A partir de então, o partido desapareceu como tal da cena política estadual, mas sobreviveu por muitos anos em algumas regiões do interior. O caso de Santa Cruz do Sul é um exemplo de sobrevivência duradoura dos "centristas" na política local, como mostrou, entre outros, Silvana Krause, em seu livro sobre a história política, social, econômica e religiosa do município (Krause, 2002). Ainda que a adesão dos "centristas" católicos ao Partido Republicano não fosse incondicional e muito menos unânime, em toda a Primeira República, vamos encontrá-los na Assembleia de Representantes integrando a bancada do PRR. Entre eles, estão os nomes de Jacob Kroeff Filho e Jacob Kroeff Neto, Luís Englert, o padre Nicolau Marx - para só citar aqueles de sobrenome alemão. ${ }^{8}$

\footnotetext{
${ }^{6} \mathrm{Um}$ estudo que tentou fazer uma medição sobre os graus de violência na década de 1880, com a finalidade de entender a violência durante a guerra civil de $1893-1895$, cons tatou que, entre as regiões de colonização alemã do estado, a região de Estrela foi uma das mais violentas durante o período (Baretta, 1985, p. 152-174).

${ }^{7}$ As informações sobre o Partido Católico ou Partido do Centro - com a indicação das fontes - podem ser conferidos em Gertz (1992).

${ }^{8}$ Uma breve avaliação das relações entre a Igreja Católica gaúcha e os republicanos nos primeiros tempos posteriores à proclamação da República pode ser vista em Isaia (1993). Mais recentemente, o mesmo autor fala de "parentesco espiritual" entre catolicismo e castilhismo (Isaia, 2007, p. 26).
} 
Abstraindo desse partido católico, desde, no mínimo, 1881, encontravam-se referências, na imprensa de língua alemã, sobre a necessidade de criar um Partido Colonial. Após a proclamação da República, falou-se dele com frequência, na mesma época em se articulava o Partido do Centro por parte de militantes católicos. Uma tentativa formal de criar esse outro partido, porém, só aconteceu após as primeiras eleições do período republicano, em setembro de 1890 . O partido apresentou um programa de 13 pontos, dos quais cabe destacar os seguintes: (i) representação autônoma da "colônia" na Assembleia estadual; (ii) revisão da divisão dos municípios, a fim de melhorar a eficácia administrativa; (v) aplicação de imposto de renda e taxação do latifúndio; (vi) eliminação dos impostos interestaduais; (ix) simplificação dos processos judiciais, diminuição de seus custos e diminuição dos custos dos inventários; (xi) fundação de uma universidade, de uma escola agroindustrialcomercial e de uma escola de parteiras; (xiii) melhoria das estradas, com a aplicação de um terço da dívida colonial nas localidades em que ela era arrecadada.

Esse partido teve entre seus maiores incentivadores os pastores August Kunert e Wilhelm Rotermund. Ao contrário do Partido do Centro, tratava-se, portanto, de um partido mais ligado a lideranças luteranas, mas ele, em nenhum momento, se apresentou como partido confessional, o que significa que também católicos podiam apoiá-lo, fato que, possivelmente, explique, ao menos em parte, as críticas que algumas lideranças católicas formulavam ao desinteresse de paroquianos para com o partido católico. Mas também esse partido sofreu pressões por parte dos grupos políticos estabelecidos. Aqueles políticos que haviam pertencido ao Partido Conservador, e agora apoiavam os republicanos, diziam que não se deveria criar um partido colonial autônomo, para concorrer com o partido do governo, que a "colônia" deveria restringir-se a organizar associações coloniais, as quais deveriam trazer suas demandas ao partido do governo e pressioná-lo para que fossem atendidas, mas não deveria fazer oposição. Os antigos liberais insistiam que, seja na forma de partido ou não, a "colônia" poderia articular-se, mas exclusivamente com vistas a suas reivindicações econômicas, pois a fundação e atuação de um partido político propriamente dito viria a prejudicar o partido do próprio Gaspar Silveira Martins, o tradicional grande amigo das populações das regiões coloniais, pois esse partido político colonial geraria desavenças entre as próprias populações "coloniais" e atiçaria o assim chamado "nativismo", isto é, as posições, sobretudo, antialemãs que havia entre muitos republicanos.
A discussão em torno do Partido Colonial se adensou até as eleições de 5 de maio de 1891 para a Assembleia Constituinte estadual. Como já se viu, os católicos acabaram conseguindo a inclusão de candidatos seus na lista eleitoral do partido republicano castilhista. ${ }^{9}$ E, na esteira dessa prática, dissidentes republicanos, antigos conservadores e antigos liberais insistiram para que também se suspendesse a discussão em torno do Partido Colonial, prometendo incluir o maior número possível de candidatos de sobrenome alemão nos seus respectivos agrupamentos políticos. No início, articularam-se três grupos para as eleições: os republicanos castilhistas (que incluíam os candidatos católicos), uma União Republicana (constituída basicamente de dissidentes republicanos em torno de Demétrio Ribeiro e de Barros Cassal), e uma União Nacional, composta, sobretudo, de antigos liberais.

Como deveriam ser eleitos 48 deputados constituintes, as listas de todos esses agrupamentos políticos apresentaram esse número de candidatos. $\mathrm{Na}$ imprensa de língua alemã, comentava-se que, numa situação ideal, essas listas deveriam conter seis candidatos de sobrenome alemão, já que se calculava que cerca de um oitavo da população gaúcha era de descendência alemã. A lista dos republicanos castilhistas, porém, apresentava apenas o nome do citado católico Luís Englert, mais um representante "operário" chamado João Stenhagen, de quem, no entanto, se dizia que de representante da "colônia alemã" só tinha o sobrenome. Noticiou-se que teria sido convidado Carlos Rheingantz, mas o mesmo teria recusado. Os dois outros grupos políticos aproveitaram para alfinetar que essa escassez de sobrenomes alemães na chapa castilhista demonstrava sua hostilidade contra a "colônia alemã". Em contrapartida, a lista da União Nacional, dos antigos liberais, continha os nomes de Ernesto Reinholdo Ludwig, Carlos Trein Filho, Jorge Frederico Fayet e Germano Hasslocher. Além disso, a Koseritz' Deutsche Zeitung noticiou que várias outras pessoas de sobrenome alemão haviam sido convidadas para essa chapa, mas, por motivos pessoais, não tinham podido aceitar. Na lista da União Republicana, dos dissidentes anticastilhistas, estavam os nomes do católico Carlos Wallau, de Guilherme Hoffmann, Jacob Arndt, João Maria von Heldt e o mesmo Carlos Trein Filho da outra lista.

Em 23 de abril de 1891, portanto menos de duas semanas antes da data marcada para as eleições, União Nacional e União Republicana resolveram juntar suas forças numa única chapa denominada Partido Republicano Federal, acordando que a primeira poderia colocar

${ }^{9}$ Cabe destacar que entre eles se encontrava Alfredo Clemente Pinto, que, mesmo não possuindo um sobrenome alemão, era um conhecido "germanófilo", isto é, uma personalidade estreitamente ligada à "colônia alemã". 
16 nomes na nova lista e a segunda 32 . Nesse rearranjo, acabaram permanecendo os sobrenomes alemães de Carlos Trein Filho, Ernesto Reinholdo Ludwig, Guilherme Hoffmann, Germano Hasslocher e Jorge Frederico Fayet. Apesar da presença dessas cinco pessoas de sobrenome alemão nesse novo aglomerado político, a imprensa de língua alemã publicou manifestações escritas, com assinaturas colhidas em muitos municípios do interior, de acordo com as quais nenhum dos citados candidatos era "colono" - quatro representavam o comércio e a indústria de Porto Alegre, e mesmo Trein Filho, que era de Santa Cruz do Sul, não era "colono".

Essas críticas, mais a vitória dos republicanos castilhistas nas eleições de 5 de maio de 1891, fizeram com que, na sequência, a discussão em torno do Partido Colonial ganhasse nova intensidade. Acompanhando-se os comentários na imprensa de língua alemã, aparecem considerações sobre o local adequado da sede (Porto Alegre ou interior); alguns propuseram que o partido deveria ser apenas um "partido de protesto", o qual, em situações concretas, se aliaria àquele partido que se dispusesse a lutar por suas demandas específicas; em outros momentos, discutiu-se sobre a própria estratégia de constituição do partido, quando foi defendida a necessidade da criação prévia de associações coloniais locais, com funções socioeconômicas, que, mais tarde, seriam, gradativamente, agregadas e transformadas em um partido político, uma ideia que, às vezes, apareceu paralela à de desistir da constituição de um partido, para fundar uma "associação agrícola”; ainda paralelo a esta última concepção, apareceu a dúvida se, mesmo que se formasse um partido político, ele não deveria ter um programa exclusivamente econômico, com a pretensão de influir nas eleições das autoridades locais, procurando, depois, supervisionar sua administração, além de lutar pela implantação do voto distrital. Nesse mesmo contexto, no entanto, ouviram-se também vozes absolutamente contrárias a uma organização em bases étnicas, pois ela, forçosamente, produziria reações contrárias de uma parte da população gaúcha e, principalmente, do governo. Ainda outros falavam da necessidade de ser realista diante da concepção de uma entidade chamada "colônia alemã", porque "as contradições dentro da família alemã deste estado são de tal ordem que não podem ser eliminadas mesmo com a melhor boa vontade daqueles que se dizem "líderes alemães"'.

Nova etapa no tratamento do tema Partido Colonial iniciou com a queda de Julio de Castilhos, em novembro de 1891, e a consequente implantação do assim chamado "governicho", o qual se estendeu até junho de 1892. Esse novo governo representou a ascensão dos republicanos dissidentes, com o apoio dos antigos liberais, de forma que readquiriu importância na cena política gaúcha aquela figura que era apresentada como o grande amigo da "colônia alemã" - Gaspar Silveira Martins. Paralelamente, ainda que em segundo plano, recebeu destaque a figura republicana dissidente de Barros Cassal, que, muitas vezes, era citado como amigo da "colônia", entre os republicanos históricos.

Todas as informações até aqui apresentadas sobre o Partido Colonial foram buscadas na imprensa, e é possível que ela não refletisse de forma adequada aquilo que efetivamente estava acontecendo. Mas, nos primeiros meses do "governicho", as discussões sobre o partido cessaram quase por completo nos jornais de língua alemã, continuando a aparecer apenas algumas poucas referências ao voto distrital, ou até referências à inexequibilidade de um partido político colonial. Isso sugere que se estava negociando com as novas autoridades ou que se enxergava nelas uma aproximação com a "colônia", a ponto de tornar supérflua a preocupação com a organização de um partido que representasse seus interesses.

Mas essa situação experimentou outra guinada, a partir de fevereiro de 1892, quando, após uma tentativa de contragolpe dos castilhistas, se desencadeou intensa repressão policial, se instaurou a censura à imprensa e foram adiadas as eleições para uma assim chamada Convenção Riograndense, que deveria elaborar uma nova constituição estadual, em substituição à castilhista de 1891. No contexto de demissões de funcionários, de intervenção em governos municipais (como em Lajeado), de extinção de comarcas (como em Santa Cruz do Sul), a discussão sobre o Partido Colonial se reacendeu.

Além disso, a lista de 35 candidatos à dita Convenção só continha dois sobrenomes alemães, Hasslocher e Ludwig, ambos de Porto Alegre e pouco representativos das "colônias" do interior. Afora os problemas citados, a retomada da discussão em torno do Partido Colonial foi influenciada por circunstâncias estratégicas. É que com a anunciada abstenção dos republicanos castilhistas nas eleições, os católicos "centristas" ficaram sem abrigo para seus candidatos. Supostas insatisfações também na "colônia italiana" abririam perspectivas de o partido extrapolar as regiões de colonização alemã. Nesse sentido, foi proposto, em março, um programa no qual se destacavam a defesa da autonomia municipal, o ensino municipalizado (ainda que subvencionado pelo estado), melhorias nas vias de transporte e favorecimento geral da atividade econômica. Montouse uma lista com 35 candidatos, dos quais 20 possuíam sobrenome alemão, e dois sobrenomes italianos; e entre os 13 restantes estavam os tradicionais supostos amigos da "colônia alemã" Gaspar Silveira Martins e Barros Cassal, mais o católico Alfredo Clemente Pinto, conhecido "germanófilo", e, ainda, o também católico "centrista" 
Francisco Lacerda de Almeida, que, provavelmente, não fosse um "nativista", isto é, um inimigo da "colônia".

Aparentemente, havia gente um tanto ingênua que acreditava nas possibilidades reais dessa chapa, pois a imprensa de língua alemã publicou conjecturações da seguinte ordem: à penúltima eleição teriam comparecido 36.000 eleitores, na última apenas 28.000 , o que sugeriria que de forma alguma compareceriam, agora, mais de 40.000 eleitores. Nesse universo, a "colônia" poderia garantir 10.000 votos. Considerando a situação conturbada, a abstenção dos castilhistas, a fragmentação do situacionismo, a atração de eleitores situacionistas pela presença de figuras de destaque, como Silveira Martins, Barros Cassal, Demétrio Ribeiro, mais a presença dos "centristas" católicos - tudo isso abriria possibilidades reais de vitória para o Partido Colonial. Houve, porém, vozes discordantes, sugerindo que a lista deveria ser entendida apenas como uma proposta de negociação para uma aliança com outro partido. Nesse caso, o Partido Colonial poderia propor a manutenção de 11 ou 12 nomes de sua nominata de 20 sobrenomes alemães.

Em 27 de abril, a proposta do Partido Colonial foi formalizada numa convenção realizada em Porto Alegre, que resultou, inclusive, num atrito público com Gaspar Silveira Martins, que não aceitava essa autonomia da "colônia" frente ao seu agrupamento político. E, logo depois, o "governicho", mais uma vez, acabou adiando as eleições e mudando as regras do jogo. O Partido Colonial acompanhou com vivo interesse a intensa discussão e toda essa movimentação - processo, que, porém, foi interrompido pelo contragolpe dos castilhistas, em 17 de junho de 1892, e sua volta ao poder.

Seguiu-se um período de muita discussão interna no partido, mas o desfecho foi muito parecido com o do Partido do Centro, lá em 1890. As lideranças porto-alegrenses acabaram tendo influência decisiva, manifestaram-se pragmáticas, acenando para uma composição com o governo castilhista, desde que atendidas algumas reivindicações. Aos cidadãos do interior do estado restou a alternativa de expressar sua discordância, como se pode ver na seguinte manifestação, publicada na Koseritz' Deutsche Zeitung, de Porto Alegre, em 13 de setembro de 1892:

Antes das eleições frustradas pela última revolução o diretório central porto-alegrense do Partido Colonial nos surpreendeu com a notícia de ter feito uma aliança com [Barros] Cassal. Antes disso, havia negociado com Sil- veira Martins. Eagora, novamente, em função de uma aliança eleitoral, estabeleceu negociaçôes com o [atual] governo, isto é, com os castilhistas. Tal procedimento traz alguma vantagem para o partido? Pensamos o contrário: terá como consequência que se dirá que o partido se posiciona de acordo com a direção de que sopra o vento.

Poucos meses depois, em novembro, aconteceu nova tentativa de golpe anticastilhista e uma intensa repressão por parte dos mesmos, com atos violentos também em regiões de colonização alemã, com destaque especial, mais uma vez, para Santa Cruz do Sul. Mas o caso mais rumoroso foi o assassinato do ex-deputado liberal Friedrich Haensel, em Porto Alegre. Nas eleições que, finalmente, se realizaram, registraram-se muitos votos anticastilhistas em municípios de colonização alemã tradicionalmente oposicionistas, como Santa Cruz do Sul, mas, em contrapartida, os castilhistas tiveram votação expressiva em outras localidades, como São Leopoldo e Caí. Isso mostrava que era difícil congregar a "colônia alemã" sob uma bandeira ou num partido político que pudesse representá-la e defender seus interesses.

A partir desse momento, as referências ao partido rarearam na imprensa de língua alemã, e ganharam espaço as discussões em torno das "Associações Coloniais" (Kolonievereine), com que, a rigor, se retomava uma proposta que alguns integrantes do próprio Partido Colonial haviam feito, no sentido de que ele deveria constituir o ponto final de uma organização iniciada nas "bases" e não uma organização que havia partido de cima para chegar às "bases". As "Associações Coloniais" eram entidades locais, cada qual com seu estatuto próprio, apesar de que houvesse um estatuto-padrão como modelo. Visavam a congregar as populações no nível distrital, para defender seus interesses mais imediatos e, sobretudo, lutar pela neutralidade frente ao confronto crescente entre "chimangos" e "maragatos", na política estadual. Ainda que essas "Associações" não conseguissem evitar problemas semelhantes aos enfrentados pelo próprio partido, tiveram algum papel na defesa da "colônia" durante a Revolução Federalista - através das famosas associações de autodefesa. ${ }^{10}$

A rigor, a situação até aqui descrita perdurou por toda a Primeira República. As regiões de colonização alemã (e também italiana) nunca aderiram de forma incondicional ao republicanismo que se impôs a partir de 1889 - ainda que os castilhistas, definitivamente vitoriosos depois de 1895, muitas vezes, ensaiassem uma cooptação da população

\footnotetext{
${ }^{10}$ As informações sobre o Partido Colonial estão esmiuçadas e com indicação das fontes em Gertz (1993a, 1993b). Apesar dos títulos praticamente idênticos, trata-se de dois textos diferentes.
} 
dessas regiões. Já vimos como o Partido Católico havia sido cooptado desde o início, com a inclusão de seus candidatos na lista dos castilhistas. Mas consta que o próprio Castilhos ainda em vida convidou um luterano - Arno Philipp - a também integrar a chapa castilhista. Castilhos morreu em 1903, e em 1905 Philipp realmente se tornou deputado, permanecendo como tal até o final da década de 1920. Mas isso não significou que católicos e luteranos, enfim, que a "colônia alemã"tivesse dado apoio incondicional e submisso ao regime republicano. Sempre que se abria alguma brecha no sistema, tentava-se explorar um caminho alternativo ou tirar algum proveito da situação crítica em que o governo se encontrava. O primeiro caso aconteceu nas eleições de 1907 a governador, quando o candidato oposicionista Fernando Abbott fez, no mínimo, metade dos seus votos nas regiões de colonização alemã (e italiana). ${ }^{11}$ Ainda que nas eleições de 1922, na disputa entre o candidato Borges de Medeiros e seu opositor Assis Brasil, a tendência da "colônia alemã" em favor de Assis Brasil não fosse escancarada, o desfecho dessa eleição, com a guerra civil de 1923 e a imposição do pacto de Pedras Altas a Borges de Medeiros, fez com que as regiões de colonização ítalo-alemã novamente aproveitassem a situação para manifestar sua tendência histórica à autonomia. ${ }^{12}$

Isso permite concluir que, se durante o período imperial não se podia partir de qualquer lógica definitiva para explicar o posicionamento da "colônia" frente à Monarquia, o mesmo continuou valendo para todo o período da Primeira República. Quaisquer afirmações "generalizantes" sobre episódios específicos ou sobre o período todo correm o risco de, no mínimo, simplificar um processo complexo, obrigando-nos, antes de qualquer veredicto, a fazer pesquisa histórica - afinal, a tarefa para a qual nós nos formamos. A única afirmação "generalizante" que não corre risco de vir a ser refutada - ainda que tenha pouca representatividade na historiografia sul-rio-grandense -é que a República, de forma nenhuma, passou despercebida nas regiões de colonização alemã (e italiana).

\section{Referências}

BARETTA, S.R.D. 1985. Political violence and regime change: A study of the 1893 civil war in Southern Brazil. Pittsburgh, EUA. Tese de doutorado. University of Pittsburgh, $275 \mathrm{p}$.

FAUSEL, E.1936.D. Dr. Rotermund: Ein Kampfum Recht und Richtung des evangelischen Deutschtums in Südbrasilien. São Leopoldo, Rotermund, $246 \mathrm{p}$.
GERTZ, R.E. 1992. Catolicismo social no Rio Grande do Sul: a União Popular. Veritas, 37(148):553-579.

GERTZ, R.E.1993a.Antecedentes da Revolução Federalista nas regiões de colonização alemã do Rio Grande do Sul. In: REUNIÃO DA SOCIEDADE BRASILEIRA DE PESQUISA HISTÓRICA, XII, Curitiba, 1993. Anais... Curitiba, SBPH, p. 193-196.

GERTZ, R.E. 1993b. Antecedentes da Revolução Federalista nas regiões de colonização alemã. In: M. FLORES (org.), 1893-95: a revolução dos maragatos. Porto Alegre, EDIPUCRS, p. 61-74.

GERTZ, R.E.1994. A Revolução Federalista nas regiões de colonização alemã no Rio Grande do Sul. In: REUNIÃO DA SOCIEDADE BRASILEIRA DE PESQUISA HISTÓRICA, XIII, Curitiba, 1994. Anais... Curitiba, SBPH, p. 273-277.

GERTZ, R.E. 2001. A eleição de 1907 nas regiões de colonização alemã do Rio Grande do Sul. In: A. SULIANI (org.), Etnias e carisma: poliantéia em homenagem a Rovilio Costa. Porto Alegre, EDIPUCRS, p. 963-976.

GERTZ, R.E. 2002. O aviador o carroceiro: politica, etnia e religião no Rio Grande do Sul dos anos 1920. Porto Alegre, EDIPUCRS, 271 p.

GERTZ, R.E. 2005. O castilhismo e a colônia alemã. In: G. AXT; R.V. SEELIG; S.T. GEDOZ; O.L. de BARROS FILHO; S.B.MENEGHETTI (orgs.), Julio de Castilhos e o paradoxo republicano. Porto Alegre, Nova Prova, p. 133-162.

GERTZ, R.E. 2006. A Câmara de Vereadores de São Leopoldo de 1846 a 1937. In: H.R.K. da SILVA; M.M. HARRES (orgs.), A história da Câmara e a Câmara na história. São Leopoldo, OIKOS, p. 56-71.

ISAIA, A.C. 1993. A Revolução Federalista: catolicismo e clivagem política no Rio Grande do Sul. In: F. das N. ALVES; L.H. TORRES (orgs.), Pensar a Revolução Federalista. Rio Grande, Editora da FURG, p. 103-108.

ISAIA, A.C.2007. Catolicismo e castilhismo.In: A.L.S. RECKZIEGEL; G. AXT (dir.), História Geral do Rio Grande do Sul: vol. 3, tomo II República Velha (1889-1930). Passo Fundo,Méritos Editora,p.23-28.

KRAUSE, S. 2002. Migrantes do tempo: vida econômica, política e religiosa de uma comunidade de imigrantes alemães na República Velha. Santa Cruz do Sul, EDUNISC, 207 p.

MOTTER, A.E. 1998. As relaçôes entre as bancadas teuta e luso-brasileira na Assembleia Legislativa provincial rio-grandense (1881-1889). São Leopoldo, RS. Dissertação de mestrado. Universidade do Vale do Rio dos Sinos, 165 p.

NOLL, M.I.;TRINDADE, H.2004. Estatísticas eleitorais do Rio Grande da América do Sul, 1823/2002. Porto Alegre, Editora da UFRGS/ Assembleia Legislativa do Estado do Rio Grande do Sul, 119 p.

OBERACKER, K.H.1978. Der deutsche Beitrag zum Aufbau der brasilianischen Nation. São Leopoldo, Federação dos Centros Culturais 25 de Julho, 579 p.

PICCOLO, H.I.L. 1982. O Partido Republicano Riograndense e os alemães no Rio Grande do Sul. Revista do Instituto de Filosofia e Ciências Humanas, X:143-156.

PINTO, C.R.J.1979. Contribuição ao estudo da formação do Partido Republicano Riograndense (1882-1891). Porto Alegre, RS. Dissertação de mestrado. Universidade Federal do Rio Grande do Sul, 148 p.

\footnotetext{
"Sobre o episódio, cf. Gertz (2001). O mapa da localização dos eleitores de Abbott pode ser visto em Trindade e Noll (1991, p. 45). Convém destacar que Abbott não era descendente de alemães, como sugere Jean Roche em seu citado livro (Roche, 1969, p. 731). Os Abbott eram ingleses que haviam vindo para a Bahia e de lá se transferiram ao Rio Grande do Sul.

${ }^{12}$ Sobre a situação nos anos 1920, cf. Gertz (2002, em especial p. 51-88). Para uma apreciação mais geral sobre todo o período da Primeira República, cf. Gertz (2005).
} 
PISTOIA, C. 2009. Violência física, material e moral no Rio Grande do Sul (1889-1920). Porto Alegre, RS. Dissertação de mestrado. Pontifícia Universidade Católica do Rio Grande do Sul, 209 p.

ROCHE, J. 1969. A colonização alemã e o Rio Grande do Sul. Porto Alegre, Globo, 806 p.

TRINDADE, H.; NOLL, M.I. 1991. Rio Grande da América do Sul: partidos e eleições (1823-1990). Porto Alegre, Editora da Universidade/Editora Sulina, 96 p.

\section{Fontes primárias}

DEUTSCHE ZEITUNG. 1880a. Porto Alegre, 3 de janeiro. DEUTSCHE ZEITUNG. 1880b. Porto Alegre, 10 de julho.
DEUTSCHE ZEITUNG. 1880c. Porto Alegre, 3 de novembro. DEUTSCHE ZEITUNG. 1889. Porto Alegre, 19 de novembro. DEUTSCHE ZEITUNG. 1890a. Porto Alegre, 6 de maio. DEUTSCHE ZEITUNG. 1890b. Porto Alegre, 22 de agosto. KALENDER FÜR DIE DEUTSCHEN IN BRASILIEN. 1903. São Leopoldo, p. 169-171.

KOSERITZ' DEUTSCHE ZEITUNG. 1892. Porto Alegre, 13 de setembro.

Submetido em: 22/12/2009

Aceito em: $11 / 01 / 2010$
René E. Gertz

Pontifícia Universidade Católica do Rio Grande do Sul Av. Ipiranga, 6681 90619-900, Porto Alegre, RS, Brasil 